\title{
EFEKTIVITAS CSR DALAM MENGANTISIPASI KRISIS MELALUI PENDEKATAN INVESTASI SOSIAL (PROGRAM CSR "MASAK BESAR 2.705 PORSI NASI GORENG” JOGJA CITY MALL)
}

\author{
Oleh: Raditia Yudistira Sujanto \\ Program Studi Komunikasi, Fakultas Ekonomi, Ilmu Sosial dan Humaniora, Universitas \\ 'Aisyiyah (UNISA) Yogyakarta. Jl. Lingkar Barat 63, Mlangi, Nogotirto, Gampling, \\ Sleman, 55292. Telp.: (0274) 4469199 \\ E-mail: sujanto.raditia@unisayogya.ac.id
}

\begin{abstract}
This research is motivated by the researchers' attention on the importance for an organization to make social investments in the community, especially in communities around the establishment of the organization. Social investment can be implemented through a program of corporate social responsibility (CSR). Implementation of CSR itself should be carried out during the pre-crisis or during the period of issue management. The object of this study is CSR Jogja City Mall (JCM), entitled "Masak Besar 2705 Porsi Nasi Goreng" in which members of the public or society were invited to participate directly in it. JCM has previously been hit by several complaints and negative attitudes from the local community. The researcher at last wanted to find out the effectiveness of the CSR program as an attempt of anticipating crises to the organization as well as a form of corporate social investment.
\end{abstract}

Keywords: social investment, CSR, issue management, crisis anticipation.

\begin{abstract}
ABSTRAK
Penelitian ini dilatarbelakangi oleh perhatian peneliti pada pentingnya bagi sebuah organisasi untuk melakukan investasi sosial dalam masyarakat, terutama dalam masyarakat sekitar berdirinya organisasi. Investasi sosial dapat dilaksanakan melalui program corporate social responsibility (CSR). Pelaksanaan CSR itu sendiri sebaiknya dilakukan selama tahap pra-krisis atau selama masa manajemen isu. Objek penelitian ini adalah program CSR Jogja City Mall (JCM) yang bertajuk "Masak Besar 2.705 Porsi Nasi Goreng" di mana anggota masyarakat diundang untuk terlibat langsung di dalamnya. JCM sendiri sebelumnya sempat dilanda beberapa keluhan dan sikap tidak suka dari pihak masyarakat sekitar. Peneliti kemudian ingin mencari tahu efektivitas program CSR dalam mengantisipasi krisis bagi organisasi sekaligus sebagai bentuk investasi sosial perusahaan.
\end{abstract}

Kata kunci: investasi sosial, CSR, manajemen isu, antisipasi krisis.

\section{A. Pendahuluan}

Pusat perbelanjaan Jogja City Mall (JCM) sebagai organisasi bisnis berbasis pelayanan jasa komersil retailing menjadi obyek penelitian dalam penelitian ini. Secara fisik gedung JCM berada di tengah lingkungan rumah-rumah masyarakat. Pada awal 
pembangunan gedung masyarakat sekitar gedung pusat perbelanjaan tersebut menunjukkan sikap antipatis atau tidak suka karena terganggu dengan kendaraan besar serta debu dan suara bising yang dihasilkan. Tidak hanya selama proses pembangunan tetapi juga pada malam hari ketika JCM menggelar acara musik rutin; masyarakat sekitar menunjukkan sikap protes kepada pihak manajemen organisasi karena mereka merasa terganggu dengan musik-musik yang dimainkan.

Upaya JCM dalam meredakan keadaan adalah melalui program tanggung jawab sosial perusahaan atau CSR (corporate social responsibility). Dari hasil pre-riset yang dilakukan oleh peneliti, ditemukan bahwa JCM mengadakan acara masak dan makan sebanyak lebih dari 2500 porsi bertajuk "Masak Besar 2.705 Porsi Nasi Goreng" di mana masyarakat diundang dan diajak memasak di dalam gedung JCM. Program ini dilaksanakan demi menjaga hubungan baik antara pihak JCM sebagai entitas bisnis yang berada di tengah lingkungan rumah-rumah masyarakat dan anggota masyarakat itu sendiri.

Program "Masak Besar 2.705 Porsi Nasi Goreng" untuk anggota masyarakat sekitar JCM tersebut di atas dinilai peneliti menarik untuk diteliti demi menjawab pertanyaan penelitian, yang kemudian lebih lanjut dapat diambil manfaatnya bagi kepentingan Universitas 'Aisyiyah Yogyakarta dalam melakukan pendekatan sosial dengan masyarakat sekitar universitas.

Tujuan penelitian ini adalah mengetahui efek sosial dari program CSR "Masak Besar 2.705 Porsi Nasi Goreng" dalam peningkatan dukungan sosial bagi pihak perusahaan terutama dalam mengantisipasi krisis.

\section{Pengertian dan Pengukuran Efektivitas}

Dari asal katanya, kata 'efektif' dalam bahasa Inggris effective berarti berhasil atau sesuatu yang dilakukan berhasil dengan baik. Efektivitas juga diartikan sebagai ketepatan kegunaan, hasil guna atau menunjang tujuan. Adapun beberapa pakar memberikan definisi tentang efektivitas, sebagai berikut.

1. Drucker (2008) mendefinisikan efektivitas sebagai melakukan pekerjaan yang benar (doing the right things).

2. Supriyono (2000) mendefinisikan efektivitas sebagai hubungan antara keluaran suatu pusat tanggung jawab dengan sasaran yang mesti dicapai, semakin besar konstribusi daripada keluaran yang dihasilkan terhadap nilai pencapaian sasaran tersebut, maka dapat dikatakan efektif pada unit tersebut.

3. Handoko (2001) mendefinisikan efektivitas sebagai hubungan antara output dan tujuan, semakin besar kontribusi (sumbangan) output terhadap pencapaian tujuan, maka semakin efektif organisasi, program atau kegiatan. Efektivitas berfokus pada outcome (hasil), program, atau kegiatan yang dinilai efektif apabila output yang dihasilkan dapat memenuhi tujuan yang diharapkan.

Dari beberapa paparan teoritis yang ada mengenai efektivitas dan kriterita pengukurannya, peneliti memilih satu teori oleh Budiani (2007) tentang bagaimana mengukur efektivitas suatu program, dengan menggunakan variabel-variabel sebagai berikut.

1. Ketepatan sasaran program - sejauhmana peserta program tepat dengan sasaran yang sudah ditentukan sebelumnya.

2. Sosialisasi program - kemampuan penyelenggara program dalam melakukan sosialisasi program sehingga informasi mengenai pelaksanaan program dapat 
Diterbitkan oleh Program Studi IImu Komunikasi

Universitas Ahmad Dahlan Yogyakarta

tersampaikan kepada masyarakat pada umumnya dan sasaran peserta program pada khususnya.

3. Tujuan program - sejauhmana kesesuaian antara hasil pelaksanaan program dengan tujuan program yang telah ditetapkan sebelumnya.

4. Pemantauan program-kegiatan yang dilakukan setelah dilaksanakannya program sebagai bentuk perhatian kepada peserta program.

Peneliti menilai keempat variabel di atas untuk mengukur efektivitas suatu program sangat sesuai dengan konteks penelitian ini.

\section{Investasi Sosial Sebagai Upaya Organisasi Mengantisipasi Krisis}

Menurut peneliti investasi sosial perlu dilakukan sebelum sebuah krisis terjadi atau melanda organisasi. Jika dibawa ke dalam konteks pembahasan di atas, investasi sosial sebaiknya dilakukan selama masa atau tahap manajemen isu atau tahap pre-crisis. Penamaan istilah mengenai hal-hal yang bernuansa investasi sosial atau masyarakat bisa cukup membingungkan. Hal tersebut dikarenakan banyak organisasi yang menggunakan istilah tersebut namun dengan rujukan ke filantrofi (philanthropy), pemberian dana untuk amal (charitable giving), tanggung jawab sosial perusahaan (corporate social responsibility), program masyarakat (community programs) dan kontribusi sosial (social contributions). Pada dasarnya tidak ada standar penamaan resmi mengenai investasi sosial. Akan tetapi, tiga nama yang paling umum digunakan oleh perusahaan-perusahaan adalah investasi masyarakat (community investment), investasi sosial (social investment), dan filantrofi (philanthropy) (KPMG International, 2014). Investasi sosial dipandang sebagai kegiatan investasi yang dilakukan oleh sebuah organisasi atau perusahaan untuk berkontribusi untuk masyarakat tanpa ada maksud langsung untuk memperoleh keuntungan finansial.

Beberapa pengertian mengenai investasi sosial oleh KPMG International (2014) meliputi:

1. Investasi dalam bentuk donasi perusahaan berupa uang tunai atau produk, employee volunteering, dan pemberian sponsor (sponsorship);

2. Investasi yang dibuat langsung oleh perusahaan, ditujukan kepada rekan perusahaan yang tidak berbasis profit (non-for-profit partners);

3. Investasi yang dilakukan secara sukarela, termasuk pelaksanaan programprogram yang diharuskan oleh pemerintah;

4. Investasi yang dilakukan secara lokal, dekat dengan aktivitas operasional perusahaan, dan seringkali dengan tujuan ingin mempererat hubungan antara perusahaan dan masyarakat setempat yang terpengaruh oleh aktivitas operasional perusahaan; dan

5. Investasi yang dilakukan secara global atau mendunia dan ditargetkan untuk keuntungan-keuntungan beberapa negara.

Peneliti, dalam penelitian ini, menitikberatkan fokusnya pada poin 4 di atas. Investasi sosial yang dilakukan dengan ruang lingkup pelaksanaan yang bersifat lokal. Dalam artian pelaksanaan atau penanaman investasi (sosial) dilakukan pada masyarakat sekitar di mana organisasi berdiri.

Dijelaskan dalam KPMG International (2014), investasi sosial dalam masyarakat menyimpan keuntungan-keuntungan yang sangat berpotensi. Keuntungan yang dimaksud meliputi memperoleh izin sosial untuk beroperasi, meningkatkan reputasi, menarik pe- 
kerja-pekerja yang bertalenta dari masyarakat sekitar, meningkatkan keterlibatan tenaga kerja, dan mengembangkan produk dan pasar yang baru.

\section{Tanggung Jawab Sosial Perusahaan}

Peneliti melihat bahwa investasi sosial dapat dilakukan melalui program sosial perusahaan atau organisasi yang melibatkan masyarakat setempat. Dalam pembahasan mengenai tanggung jawab perusahaan (corporate responsibility) secara umum, perusahaan atau organisasi bisnis memiliki tiga tanggung jawab, meliputi tanggung jawab ekonomi (economic responsibility), tanggung jawab hukum (legal responsibility), dan tanggung jawab sosial (social responsibility). Tanggungjawab sosial (social responsibility), menurut Robbins \& Coutler (2010) didefinisikan sebagai intensi bisnis, melampaui kewajiban hukum dan ekonominya, untuk melakukan hal yang benar dan bertindak dengan cara yang baik bagi masyarakat.

Tabel 2.1 Argumen yang Mendukung Tanggung Jawab Sosial

(Robbins \& Coutler, 2010)

\begin{tabular}{|c|l|}
\hline 1 & $\begin{array}{l}\text { Ekspektasi Publik - Opini publik sekarang mendukung bisnis yang mengejar tujuan } \\
\text { ekonomi dan sosial }\end{array}$ \\
\hline 2 & $\begin{array}{l}\text { Profit Jangka Panjang - Perusahaan bertanggungjawab secara sosial cenderung } \\
\text { mempunyai profit jangka panjang yang lebih pasti }\end{array}$ \\
\hline 3 & $\begin{array}{l}\text { Kewajiban Etis - Bisnis harus mempunyai tanggung jawab sosial karena tindakan yang } \\
\text { bertanggungjawab merupakan hal yang benar untuk dilakukan }\end{array}$ \\
\hline 4 & $\begin{array}{l}\text { Citra Publik - Bisnis dapat menciptakan citra publik yang baik dengan mengejar tujuan } \\
\text { sosial }\end{array}$ \\
\hline 5 & $\begin{array}{l}\text { Lingkungan yang Lebih Baik - Keterlibatan bisnis dapat membantu pemecahan masalah } \\
\text { sosial yang sulit }\end{array}$ \\
\hline 6 & $\begin{array}{l}\text { Pelonggaran Peraturan Pemerintah - Dengan bertanggungjawab secara sosial, bisnis } \\
\text { dapat mengharapkan berkurangnya peraturan pemerintah }\end{array}$ \\
\hline 7 & $\begin{array}{l}\text { Penyeimbang Tanggung Jawab dan Kekuasaan - Bisnis mempunyai banyak kekuasaan } \\
\text { dan tanggung jawab yang sama besarnya diperlukan untuk menandingi kekuasaan } \\
\text { tersebut }\end{array}$ \\
\hline 8 & $\begin{array}{l}\text { Kepentingan Pemegang Saham - Tanggung jawab sosial akan meningkatkan harga } \\
\text { saham dalam jangka panjang } \\
\text { publik dan proyek amal yang membutuhkan bantuan }\end{array}$ \\
\hline 9 & $\begin{array}{l}\text { Mengutamakan Pencegahan Daripada Perbaikan - Bisnis seharusnya mengatasi } \\
\text { masalah sosial sebelum mereka menjadi lebih serius dan makin mahal untuk diperbaiki }\end{array}$ \\
\hline
\end{tabular}


Diterbitkan oleh Program Studi IImu Komunikasi

Universitas Ahmad Dahlan Yogyakarta

Peneliti sangat setuju dengan poin 10 dalam tabel 2.1 di atas yang menyatakan bahwa tanggung jawab sosial perusahaan atau organisasi menjadi upaya pencegahan (yang lebih baik daripada aksi perbaikan). Dalam konteks penelitian ini, argumen tersebut bersifat sangat mendukung.

Adapun istilah khusus bagi tanggung jawab perusahaan dalam bidang sosial adalah corporate social responsibility atau sering disebut CSR.

\section{B. Metode Penelitian}

Penelitian ini menggunakan pendekatan kualitatif yang berbentuk studi kasus. Peneliti memutuskan untuk menggunakan pendekatan kualitatif karena dirasa paling tepat dalam mendapatkan pemahaman yang mendalam atas suatu fenomena atau kasus. Poerwandari (2001) mengatakan, untuk mendapatkan pemahaman yang mendalam dan khusus atas suatu fenomena serta untuk dapat memahami manusia dalam segala kompleksitasnya sebagai makhluk subjektif, pendekatan kualitatif merupakan metode yang paling sesuai untuk digunakan.

Penelitian studi kasus ini menggunakan suatu pendekatan yang bertujuan untuk mempertahankan keutuhan dari objek penelitian. Data yang terkumpul dipelajari sebagai satu kesatuan yang tujuannya adalah untuk mengembangkan pengetahuan yang mendalam mengenai objek yang diteliti.

Adapun alat pengumpulan data yang digunakan oleh peneliti untuk mengungkap penelitian ini adalah wawancara mendalam.

Ciri umum yang dikenal dari penelitian studi kasus adalah pemahaman yang mendalam mengabaikan representasi sub penelitian terhadap masyarakat, tidak menggunakan sampel besar dan tidak dianalisis dengan menggunakan angka statistik.

Analisis data dalam metode studi kasus ini bergantung pada pemikiran logis dan imajinasi dari peneliti. Bentuk analisis data kualitatif diperlukan untuk membandingkan antara kenyataan dengan teori (Suryabrata, 1992).

Data penelitian kualitatif tidak berbentuk angka, tetapi lebih banyak berupa narasi, deskripsi, cerita, dokumen tertulis dan tidak tertulis (wawancara), maupun bentuk-bentuk non angka lain (Poerwandari, 2001).

\section{Hasil dan Pembahasan}

Penelitian dilaksanakan di lingkungan internal dan eksternal Jogja City Mall Management di bawah perusahaan induk PT. Garuda Mitra Sejati. Penelitian dilaksanakan dengan metode wawancara mendalam.

Peneliti berhasil mewawancarai pihak internal dan pihak eksternal perusahaan. Berikut daftar informan yang berhasil dijadikan sumber informasi dalam penelitian ini. 


\begin{tabular}{|l|l|}
\hline \multicolumn{1}{|c|}{ Posisi/Peran Informan } & Nama Lengkap Informan \\
\hline $\begin{array}{l}\text { Public Relations Officer (PRO) Jogja City Mall - Ketua } \\
\text { Pelaksana Program CSR "Masak Besar" }\end{array}$ & (Ibu) Claudia Varinda Putri \\
\hline $\begin{array}{l}\text { Kepala Divisi Marketing Communications/Event and } \\
\text { Promotion (EP) Jogja City Mall }\end{array}$ & (Ibu) Lia Amalia \\
\hline Kepala Divisi Building Service (BS) Jogja City Mall & (Bapak) S. Jony Yudyantara \\
\hline Sekretaris General Manager (GM) Jogja City Mall & (Ibu) Yeyen Viki S. R. \\
\hline Kepala Divisi Human Resource (HRD) Jogja City Mall & (lbu) Trenawati \\
\hline Legal Officer Jogja City Mall & (Ibu) Reny Setyawati \\
\hline Ketua RT 5 & (Bapak) Mukidi \\
\hline
\end{tabular}

\section{Tahap Manajemen Program}

a. Perencanaan dan Pengorganisasian Program

Public Relations Officer (PRO) JCM selaku ketua pelaksana program "Masak Besar 2705 Porsi Nasi Goreng" mengungkapkan bahwa proses perencanaan dilakukan melalui rapat atau pertemuan dengan bagian-bagian terkait dari lingkup internal manajemen JCM. Ketika ditanya apakah ada pembentukan kepanitiaan khusus, jawabannya 'tidak ada' . Selama proses perencanaan, yang dilakukan adalah koordinasi rutin dengan setiap kepala bagian dan beberapa staf terkait di dalam forum khusus pembahasan rencana pelaksanaan program. Dan, dikatakan pula bahwa koordinasi semacam ini sudah menjadi tradisi atau kebiasaan bagi manajemen JCM — jarang ada pembentukan kepanitiaan secara khusus, terlebih lagi menggunakan surat tugas atau surat penunjukkan.

Dalam proses perencanaan program juga dibahas siapa saja pihak eksternal yang akan digandeng untuk diajak bekerja sama. Belajar dari ketidakberhasilan di program yang serupa sebelumnya di pusat perbelanjaan yang berbeda, PRO JCM menyadari kali itu harus ada perubahan yang lebih mendukung ke arah keberhasilan program. Yang menjadi perbedaan dari program kali itu adalah keterlibatan lebih banyak pihak eksternal yang menjadi rekan kerjasama program. Adapun beberapa pihak eksternal yang berhasil diajak kerjasama meliputi Indonesian Chef Association (ICA), SMK Tataboga, hotel-hotel di Yogyakarta dan Magelang, dan pihak media. ICA mengirimkan sebanyak 35 chef dari 35 hotel di Yogyakarta dan Magelang. SMK Tataboga mengirimkan siswanya sebanyak 10 orang. Pihak media yang diundang sebanyak 35 media (cetak, daring, televise dan radio).

Kerjasama yang terjalin selama proses perencanaan program itu bersifat sukarela, dengan kata lain pihak JCM tidak mengeluarkan biaya apapun untuk menghargai pihak kerjasama. Hal ini dapat terjadi karena masing-masing pihak eksternal berhasil diyakinkan oleh pihak JCM bahwa mereka juga bisa sekalian berpartisipasi sebagai bentuk dari program CSR dari masing-masing institusinya. Dapat dikatakan program "Masak Besar 2705 Porsi Nasi Goreng" yang dilakukan JCM bukan hanya program CSR JCM melainkan gabungan dari program CSR institusi atau pihak kerjasama program. 
Diterbitkan oleh Program Studi IImu Komunikasi

Universitas Ahmad Dahlan Yogyakarta

Karena ini merupakan program sosial JCM maka masyarakat sekitar perusahaan adalah target sasaran program. Sebanyak 550 undangan dan voucher disebarkan ke warga sekitar. Jumlah 550 pun dihitung berdasarkan data yang telah diarsipkan oleh JCM dari program-program sebelumnya. Jumlah itu sudah meliputi semua KK yang berada di lingkungan sekitar JCM. Alur komunikasi persebaran undangan kepada warga sekitar dilakukan dari pihak SDM dan General Affairs, lalu disampaikan ke ketua RW, lalu dari RW turun ke ketua RT, lalu dari RT ke setiap KK. Alur komunikasi ini dinilai efektif alihalih pihak JCM turun secara acak membagikan undangan secara langsung orang per orang.

Dalam proses perencanaan ini pula dibicarakan alasan mengundang warga sekitar. Dalam wawancaranya, PRO JCM mengatakan bahwa JCM memang berniat dari awal perencanaan program (sebulan sebelum hari pelaksanaan) untuk meningkatkan hubungan baik yang sudah terjalin selama ini dengan warga sekitar, dan tidak lupa untuk mendapatkan dukungan sosial juga. PRO JCM mengatakan, selain JCM secara rutin melakukan program CSR kepada warga melalui sumbangan sembako dan kehadiran di acaraacara/hajatan warga, tidak berarti mereka merasa cukup. Melalui program CSR masak besar ini, JCM berharap dan berniat untuk meningkatkan hubungan baik yang sudah ada.

\section{b. Pelaksanaan Program}

Mengenai pelaksanaan program peneliti mewawancarai PRO JCM, kepala divisi Marketing Communication/Event and Promotion (EP), sekretaris General Manager JCM, dan kepala divisi Building Service (BS).

Program atau acara bertajuk "Masak Besar 2705 Porsi Nasi Goreng” dilaksanakan pada 26 Mei 2016, sehari sebelum tanggal ulang tahun Jogja City Mall. Acara diadakan di bagian drop off selasar (outdoor) muka JCM, tanpa tenda, jadi bersifat terbuka untuk umum. Persiapan dilakukan pukul 14.00 WIB dengan menyiapkan kompor dan bahanbahan masak. Acara masak dimulai pukul 15.00 WIB. Di luar ekspektasi pihak pelaksana program, acara yang sebelumnya baru akan berakhir pukul $18.00 \mathrm{WIB}$, pada kenyataannya sudah berakhir pukul 16.30 WIB. Hal tersebut dikarenakan antusias dan jumlah kehadiran pengunjung dan warga yang tinggi sehingga porsi yang sudah dipersiapkan lebih cepat habis.

Diceritakan dalam wawancara, PRO JCM melihat antusias warga dan pengunjung tinggi ketika sebagian warga ikut serta secara sukarela untuk bantu memasak tanpa disuruh. Selain itu, pengunjung dan warga tidak kemudian pergi meninggalkan lokasi masak setelah mengambil dan menikmati nasi goring namun justru tetap tinggal di tempat sambil menyaksikan dan menikmati momen acara.

PRO JCM memiliki ide yang cerdik ketika akan mengadakan acara masak besar ini. Ia mengerti acara ini benar-benar bersifat sosial dan kental dengan keterlibatan tenaga manusia di dalamnya. Selain para chef yang memegang kompor dan memasak, pihak media yang diundang dan akan meliput pun diarahkan untuk ikut berada di balik kompor dan ikut serta. PRO JCM menyadari, dengan keterlibatan langsung seperti itu, pihak-pihak media yang hadir akan dengan lebih tulus mengabadikan momen mereka ber-CSR dan hasil liputanpun akan lebih alamiah. PRO JCM mengatakan hal tersebut akan bisa berbeda ketika 
pihak media hanya diundang untuk melakukan liputan semata. Namun dengan mereka terlibat secara langsung dan turut ber-CSR, liputanpun akan lebih tulus dan organik.

Prinsip yang dipegang oleh PRO JCM pada pelaksanaan program masak besar saat itu adalah keterlibatan warga dan pengunjung secara langsung. Tidak hanya ditawarkan makanan gratis tapi warga dan pengunjung turut memegang wajan dan memasak juga. Menurut PRO JCM, CSR itu akan terasa lebih efektif ketika efeknya tersimpan di ingatan target program dan pihak manajemen JCM sendiri.

Sebanyak 2875 piring dan porsi yang sudah dipersiapkan sebelumnya, ternyata pihak pelaksana kekurangan piring dan harus menambah sekitar 200 lebih porsi. Hal ini membuktikan bahwa antusias masyarakat lebih tinggi dari ekspektasi pihak pelaksana program.

Sekretaris GM JCM, dalam wawancara, mengatakan bahwa selama pelaksanaan program semua staf JCM yang sedang tidak ada kerjaan yang mendesak secara sukarela turun ke lokasi acara masak besar untuk membantu apapun yang bisa dilakukan, baik itu menyiapkan bahan maupun membeli perlengkapan yang sempat habis. Dijelaskan juga bahwa selama pelaksanaan pihak Board of Directors sampai turut menyumbangkan tenaganya untuk ikut memasak di acaranya. Hal tersebut bisa sampai terjadi karena melihat antusias masyarakat dan pihak kerjasama yang tinggi sehingga acara benar-benar terasa semarak dan meriah.

Kepala divisi EP mengatakan dalam wawancaranya bahwa program ini dalam pelaksanaannya sangat mengedepankan keterlibatan setiap staf manajemen JCM. Pada proses perencanaan para staf sudah dikabari untuk ikut terlibat membantu selama pelaksanaan acara secara sukarela. Kebersamaan menjadi salah satu inti dari pelaksanaan program CSR ini, karena CSR bersifat sosial jadi pelaksanaannya pun harus kental keterlibatan sosial yang tinggi.

Kepala divisi BS mengatakan dalam wawancaranya bahwa program CSR ini tentunya dapat meningkatkan kualitas hubungan dengan warga sekitar dan pengunjung JCM karena keterlibatan langsung dan mengundang warga untuk masuk ke dalam lingkungan internal JCM dapat memberikan kesan personal yang positif. Kepala divisi BS mengatakan bahwa awalnya tidak banyak warga sekitar yang masuk ke dalam JCM dikarenakan tidak merasa "percaya diri", sehingga ketika mereka diundang secara pribadi melalui undangan yang disebar, mereka bisa lebih "berani" untuk masuk ke dalam lingkungan internal JCM. Kepala divisi BS yakin bahwa ada efek sosial tersendiri dari acara CSR ini ketika warga memang secara khusus diundang ke "dalam". Mereka bisa merasa bahwa JCM membuka pintu untuk mereka secara sosial dan tidak ingin menjadi musuh masyarakat.

\section{c. Evaluasi Program}

Dalam tahap evaluasi ini peneliti mewawancarai PRO JCM, kepala divisi BS dan warga sekitar JCM.

PRO JCM mengatakan tidak ada evaluasi khusus yang dilakukan sejak acara selesai terlaksana, terutama evaluasi khusus terhadap pandangan warga. Namun begitu, PRO JCM dapat melihat dan merasakan selama proses pelaksanaan acara bahwa programnya berhasil dan efektif. Antusias dan keterlibatan warga ketika langsung turun ke 
Diterbitkan oleh Program Studi IImu Komunikasi

Universitas Ahmad Dahlan Yogyakarta

kompor untuk memasak tanpa disuruh adalah dua bentuk keberhasilan program yang terjadi secara tulus dan alamiah. Kepuasan tersebut yang menjadikan PRO JCM menilai bahwa acara pada saat itu sudah efektif.

Kepala divisi BS mengatakan bahwa tidak ada memang keluhan dari warga mengenai acara masak besar yang dilaksanakan saat itu. Sayangnya tidak ada evaluasi khusus mengenai efektivitas acara dari sudut pandang warga setelah acara dilaksanakan, walau memang staf BS lebih jarang menerima keluhan dari warga lagi. Kepala divisi BS yakin acara masak besar saat itu memberikan efek sosial dan kedekatan sosial yang besar.

Tanggapan dari salah satu ketua RT mengatakan bahwa JCM melakukan hal yang positif dengan mengundang warga untuk masuk ke lingkungan JCM yang mana selama ini CSR lebih ke bentuk sumbangan sembako dan kehadiran di hajatan warga. Menurut beliau tidak ada salahnya dengan mengundang warga-warga untuk masuk ke dalam JCM dan melibatkan mereka ke dalam acara walau sifatnya sukarela. Dengan besarnya jumlah warga yang hadir ke acara tersebut, menurut beliau, hal ini membuktikan bahwa warga tidak apatis terhadap kegiatan atau aktivitas JCM. Pernyataan tersebut sebenarnya didukung oleh pernyataan PRO JCM dalam wawancaranya, bahwa sebenarnya terdapat oknum-oknum yang sengaja berusaha menciptakan tuntutan dan kericuhan yang tidak masuk akal, yang bersifat tidak representatif dari persepsi sebagian besar warga sekitar JCM.

d. Pengukuran Efektivitas Program CSR "Masak Besar 2705 Porsi Nasi Goreng" Jogja City Mall

Dalam teori mengenai efektivitas dan kriteria pengukurannya, Budiani (2007) menggunakan variabel-variabel berikut yang disertai dengan pembahasan:

1. Ketepatan sasaran program - sejauhmana peserta program tepat dengan sasaran yang sudah ditentukan sebelumnya.

JCM dari tahap proses perencanaan program sudah menargetkan sasarannya, yaitu pengunjung dan warga yang tinggal di sekitar perusahaan. Dari proses perencanaan yang diperkirakan akan dihadiri kurang dari 3000 pengujung dan warga, pada kenyataannya saat pelaksanaan yang hadir melebihi 3000 orang. Program CSR saat itu memang ditujukan untuk pengunjung dan seluruh warga sekitar perusahaan, dan dengan adanya undangan yang dibawa oleh warga, terbukti antusias warga cukup tinggi untuk ikut serta ke acara tersebut.

2. Sosialisasi program - kemampuan penyelenggara program dalam melakukan sosialisasi program sehingga informasi mengenai pelaksanaan program dapat tersampaikan kepada masyarakat pada umumnya dan sasaran peserta program pada khususnya.

Selaku ketua pelaksana program, PRO JCM melakukan sosialisasi melalui media-media sosial milik perusahaan. Kepada warga sekitar perusahaan yang adalah target sasaran utama selain pengunjung, JCM melakukan sosialisasinya menggunakan koordinasi dengan RW yang kemudian diturunkan ke RT lalu setiap RT menemui setiap KK yang termasuk di dalamnya. Sosialisasi dilakukan melalui surat undangan sebanyak 550 lembar yang sudah disesuaikan dengan jumlah warga yang termasuk di dalam lingkungan sekitar perusahaan.

3. Tujuan program - sejauhmana kesesuaian antara hasil pelaksanaan program dengan tujuan program yang telah ditetapkan sebelumnya. 
Tujuan awal program CSR JCM saat itu adalah (a) meningkatkan hubungan baik yang sudah terjalin dengan warga sekitar perusahaan, dan (b) mendapatkan dukungan sosial. Hasil yang diperoleh setelah diadakannya program CSR itu adalah warga sangat puas dan senang bahwa JCM sudah mengundang secara langsung untuk warga masuk ke dalam lingkungan JCM. Kepala divisi BS pun mengungkapkan program ini bisa dirasakan di lapangan (pekerjaan BS sangat erat dengan bertemu dengar warga baik itu secara formal maupun informal). Ia mengatakan bahwa program semacam ini (mengundang warga masuk ke dalam lingkungan JCM) dirasa menurunkan tingkat keminderan dan jarak sosial antara JCM dan warga sekitar. JCM menginisiasi jalinan pertemenan dengan warga sekitar dengan mengundang mereka secara khusus.

4. Pemantauan program - kegiatan yang dilakukan setelah dilaksanakannya program sebagai bentuk perhatian kepada peserta program.

Pihak JCM mengaku tidak ada program atau bentuk khusus untuk mengevaluasi program yang telah dijalankan karena pada dasarnya salah satu operasi bisnis utama pusat perbelanjaan pada umumnya adalah mengadakan acara atau program untuk menghibur pengunjung. Namun, pihak pelaksana program dapat merasakan bahwa program CSR saat itu tergolong berhasil dan efektif dalam lebih mendekatkan diri perusahaan dengan warga sekitar serta pengunjung. Tidak ada keluhan selama pelaksanaan program ataupun setelah program selesai.

PRO JCM mengatakan akan mengadakan acara serupa di hari pertama Ramadhan tahun 2017 ini dikarenakan keberhasilan program sebelumnya. Konsep yang akan dibawa adalah suasana Ramadhan sehingga menu pilihannya bernuansa Ramadhan. Pihak yang akan diajak bekerjasama pun akan berbeda, disesuaikan dengan temanya, seperti salah satunya anak-anak yatim.

\section{Pelaksanaan Manajemen Isu yang Baik oleh Manajemen Jogja City Mall}

Dalam teori manajemen isu ada tiga hal yang dapat dilakukan, menurut Kriyantono (2015) yang disertai dengan pembahasan, yaitu:

1. Menyeleksi isu - isu dapat berupa isu jangka pendek (satu tahun ke depan) atau jangka panjang (lebih dari satu tahun). Yang dipentingkan dalam proses selektif ini adalah pembatasan jumlah dan penentuan prioritasnya, yaitu memilih isu yang paling berpengaruh pada organisasi.

JCM memiliki beragam program CSR yang bersifat rutin seperti pemberian sembako setiap bulan dan menghadiri hajatan warga, selain program CSR filantrofi yang bersifat insidentil lainnya. Program 'masak besar' saat itu berbeda dengan program CSR rutin dan insidentil JCM lainnya karena kali ini warga secara fisik diundang hadir untuk masuk ke dalam lingkungan JCM dan berbaur diri dengan anggota-anggota JCM (dalam hal ini karyawan dan jajaran atas manajemen) dalam satu acara yang menyenangkan dan menghibur.

Salah satu isu yang dimiliki JCM dengan warga sekitar sejak awal berdirinya perusahaan di tengah-tengah lingkungan warga adalah jarak sosial antara kedua pihak. Warga sempat merasa kehadiran JCM akan mengganggu stabilitas mereka. Namun dengan segala pendekatan sosial yang diupayakan JCM terhadap warga 
Diterbitkan oleh Program Studi IImu Komunikasi

Universitas Ahmad Dahlan Yogyakarta

sekitarnya, JCM berhasil menjadikan warga bagian dari mereka. Dan, dengan mengundang langsung ke dalam lingkungan perusahaan seperti saat itu, kedekatan sosial yang sudah dibangun menjadi makin erat. Ini merupakan kegiatan menyeleksi isu. Yang diutamakan oleh JCM pada saat itu adalah keterlibatan warga secara langsung, sebelum ke arah branding. JCM merasa ada kebutuhan yang tidak kalah pentingnya untuk memiliki kedekatan yang erat secara sosial dan personal dengan warga sekitar.

2. Menentukan strategi untuk merespon isu - beberapa kemungkinan atau faktorfaktor yang memicu ketidakpuasan publik mesti ditangani sedini mungkin dengan cara mengidentifikasi penyebab ketidakpuasan dan memberikan perhatian penuh terhadapnya.

Seperti yang sudah dibahas sebelumnya, program 'masak besar' saat itu merupakan strategi JCM untuk dapat meningkatkan hubugan baik yang sudah terjalin dengan warga sekitar. Strategi ini dilakukan karena pertemuan fisik antara pihak perusahaan yang diwakili oleh karyawan dan jajaran atas manajemen JCM dengan warga-warga sekitar dapat memberikan efek yang berbeda daripada sekadar memberikan sumbangan semata. Dengan bercengkrama secara fisik dan tanpa ada jarak sosial dalam satu acara kolaboratif seperti saat itu, kualitas hubungan menjadi meningkat. Warga memiliki kepercayaan terhadap ketulusan JCM dalam menjadikan mereka bagian dari perusahaan. Layaknya hubungan sosial pada umumnya, hubungan pertemanan yang hanya berbentuk surat-menyurat akan berbeda ketika teman tersebut diundang untuk bertemu secara fisik dan saling bercengkrama secara langsung, terlebih lagi dapat melakukan satu kegiatan yang menyenangkan bersama. Begitu lah yang coba dilakukan oleh JCM dengan warganya; mengundang warga untuk hadir langsung ke dalam lingkungan JCM untuk bertemu dan berkegiatan bersama dengan para karyawan JCM serta jajaran atas manajemennya dapat meningkatkan kualitas hubungan sosial yang ada antar kedua pihak.

3. Mencari peluang untuk reposisi organisasi

Seperti yang sempat diungkapkan dalam tahap penyeleksian isu di atas, JCM merasa perlu mengadakan kedekatan secara sosial dengan warga lebih erat lagi melalui program 'masak besar' saat itu. Dalam melakukan program CSR secara umum yang terpenting adalah keberlanjutan. Walau sebelum diadakannya program 'masak besar' hubungan dengan warga sudah cenderung tidak bermasalah, akan tetapi tidak berarti meningkatkan kualitas hubungan tidak perlu lagi dijadikan salah satu fokus perhatian perusahaan. JCM merasa perlu meningkatkan kualitas program demi makin eratnya kedekatan sosial dengan warga, dari yang sebelumnya lebih bersifat filantrofis kemudian bervariasi dengan pendekatan kolaboratif. Dengan begitu warga dapat merasakan adanya kepercayaan terhadap keberadaan JCM sebagai bagian dari hidup sosial mereka.

\section{CSR Dilakukan Sebagai Bentuk Investasi Sosial oleh Jogja City Mall}

Dalam pembahasan mengenai investasi sosial sebagai upaya perusahaan dalam mengantisipasi krisis, KPMG International (2014) memberikan beberapa bentuk investasi sosial, yang disertai dengan pembahasan, sebagai berikut: 
a. Investasi dalam bentuk donasi perusahaan

Secara rutin JCM melakukan sumbangan dalam bentuk sembako dan sponsorship ketika warga mengadakan acara di lingkungannya.

b. Investasi tidak berbasis profit melalui kerjasama dengan rekan perusahaan

Program 'masak besar' dikatakan oleh PRO JCM adalah salah satu yang memakan biaya paling sedikit. PRO JCM mengedepankan rekan perusahaan dan rekan atau koneksi pribadi PRO JCM ia sendiri. Berikut penjabaran bentuk kerjasama non profit yang dimaksud.

1) Kerja sama dengan Indonesian Chef Association (ICA). Kerja sama ini bersifat tidak berbiaya sedikit pun karena JCM dan ICA sepakat untuk melakukan program sosial (CSR) secara kolaboratif berdasarkan hasil dari rapat-rapat inisiasi dengan kedua belah pihak. ICA secara sukarela menyumbangkan sebanyak 35 chef dari 35 hotel yang terletak di Yogyakarta dan Magelang. ICA sendiri merasa dengan menyumbangkan tenaga chefnya tersebut, adalah program sosial (CSR) bagi asosiasinya.

2) Kerja sama dengan salah satu SMK Tataboga. Kerja sama ini terjalin atas bantuan ICA yang sebelumnya sudah memiliki bentuk kerja sama serupa dengan pihak SMK yang bersangkutan.

3) Kerja sama dengan rekan media. Kerja sama ini ditekankan oleh JCM melalui PRO-nya di awal pengundangan rekan medianya bahwa undangan bukan untuk meliput melainkan untuk berkolaborasi. Rekan media sebanyak 25 media diundang untuk turut membantu memasak atau menyiapkan bahanbahan atau membantu berjalannya kegiatan. JCM sudah memiliki hubungan baik dengan rekan media dari sebelumnya. Setiap kali ada tenant yang baru buka dan mengadakan soft-opening rekan media akan turut diundang. Hubungan baik ini kemudian melahirkan kesukarelawaan rekan media untuk mau berkolaborasi dalam kegiatan program 'masak besar' saat itu. PRO JCM mengatakan, dengan begitu, hasil liputan dari rekan media akan bersifat lebih organik dan alamiah karena mereka terlibat langsung di dalamnya sebagai bentuk kegiatan sosial mereka sendiri.

4) Kerja sama dengan hotel dan pemasok. Untuk keperluan bahan masak seperti nasi dan bumbu-bumbu, Hotel Sahid Rich menyumbangkan sebagian bahan dari dapur mereka untuk digunakan di program 'masak besar' saat itu. Kokita sebagai pemasok bahan dasar masak saat itu pun turut menyumbangkan bumbu-bumbu siap masak mereka, sebagai kegiatan sosial mereka sendiri. Hal ini tidak akan terjadi jika tidak ada hubungan baik sebelumnya.

\section{Investasi dilakukan secara sukarela}

Dalam teori yang dikemukakan oleh Philip Kotler ada satu bahasan mengenai bentuk sosial perusahaan, yaitu community volunteering atau kesukarelawaan ke komunitas. JCM melalui program 'masak besar' sangat melibatkan keterlibatan sukarela dari banyak pihak yang telah disebutkan sebelumnya, meliputi pihak internal perusahaan (karyawan dan jajaran atas manajemen) dan pihak eksternal (rekan kerjasama dan warga sebagai target sasaran program). 
Diterbitkan oleh Program Studi IImu Komunikasi

Universitas Ahmad Dahlan Yogyakarta

Kesukarelawaan rekan kerjasama atau kemitraan tidak kemudian muncul tanpa adanya hubungan baik yang sebelumnya dibangun oleh perusahaan. Seorang PRO dalam perusahaan secara umum harus memastikan hubungan dengan pihak terkait kegiatan perusahaan (publik perusahaan) dalam kualitas yang baik dan terus ditingkatkan. Investasi bersifat jangka panjang sehingga perusahaan yang memiliki prinsip seperti itu akan mendapatkan kemudahan ketika membutuhkan bantuan atau kerja sama dari publiknya.

2. Investasi dilakukan secara lokal, dekat dengan aktivitas operasional perusahaan, dan seringkali dengan tujuan ingin mempererat hubungan antara perusahaan dan masyarakat setempat yang terpengaruh oleh aktivitas operasional perusahaan

Hal ini sudah jelas bagaimana dalam proses perencanaan program, seperti yang telah disebutkan sebelumnya, pihak pelaksana program menujukan program untuk meningkatkan hubungan dengan warga sekitar perusahaan yang menjadi target sasaran program, serta mendapatkan dukungan sosial. PRO JCM selaku ketua pelaksana program menjelaskan bahwa itu lah nilai penting dari pelaksanaan program sosial atau CSR, yaitu meningkatkan hubungan baik dengan masyarakat dan mendapatkan dukungan sosial.

Masyarakat yang tinggal dekat dengan aktivitas operasional perusahaan tentunya mendapatkan dampak langsung dari kegiatan perusahaan. Dalam konteks aktivitas JCM hal-hal yang mungkin mempengaruhi secara langsung adalah truk-truk pengangkut sampah yang menggunakan akses jalan di belakang gedung setiap harinya, aroma sampah yang terkadang tercium di sekitar penyimpanan sampah, kebisingan dari kendaraan-kendaraan bermotor yang keluar melewati akses belakang, jalanan warga menjadi rusak, kebisingan dari pertunjukkan-pertunjukkan hiburan di panggung pada malam hari, dan sebagainya.

Dengan dasar pemahaman isu-isu tersebut, pihak JCM merasa perlu kemudian membangun hubungan baik dengan warga demi tidak terjadinya krisis yang lebih besar atau bahkan konflik fisik dari warga. Dalam bahasan CSR, pemerolehan social license atau izin sosial dari masyarakat sekitar perusahaan sangat perlu dipentingkan. Dalam kasuskasus lain, misalnya, penolakan izin bangun perusahaan dapat berbentuk pemblokadean jalan, unjuk rasa di depan perusahaan, kerusuhan, dan lainnya. Oleh karena itu, antisipasi sebelum terjadinya krisis yang akut, perlu tindakan-tindakan dan pendekatan-pendekatan yang tepat dengan masyarakat. Pemahaman isu yang dilakukan dengan tepat akan menghasilkan tindakan dan pendekatan yang tepat pula. Bagi beberapa perusahaan, filantrofi dianggap efektif dalam membeli hati masyarakat untuk memberikan izin berdiri perusahaan. Itu lah yang sering menjadi masalah di lapangan.

\section{Investasi dilakukan secara global atau mendunia}

Dalam konteks ruang lingkup penelitian ini, investasi poin kelima ini dirasa tidak memiliki relevansi yang sesuai.

\section{Kesadaran Jogja City Mall Mengenai Pentingnya Program Sosial (CSR)}

Pembahasan mengenai CSR dapat didasarkan pada argumen yang diberikan oleh Robbins \& Coutler (2010). Dari 10 argumen yang ada (seperti yang telah dipaparkan dalam 
bahasan Tinjauan Pustaka), peneliti memilah beberapa argumen yang tepat untuk konteks bahasan penelitian ini, yaitu:

1. Ekspektasi Publik - opini publik sekarang mendukung bisnis mengejar tujuan ekonomi dan sosial

Pihak JCM menyadari keberadaan perusahaan tanpa dukungan atau izin sosial hanya akan menjadikan perusahaan tidak berdiri lama. Hal ini berkaitan dengan investasi sosial poin keempat di atas yang membahas tentang pentingnya mempererat hubungan sosial dengan masyarakat. Jika JCM tidak menyadari pentingnya hal tersebut, tidak mungkin akan terlahir ide untuk melibatkan masyarakat dan upaya-upaya lain dalam mendekatkan ikatan dengan masyarakat.

2. Profit Jangka Panjang - perusahaan bertanggungjawab secara sosial cenderung mempunyai profit jangka panjang yang lebih pasti

Pembahasan penelitian ini adalah investasi (sosial). JCM melakukan investasi sosial dengan meningkatkan kualitas pendekatan sosial dengan warga sekitar. Programprogram yang dijalankan sebelumnya lebih bersifat filantrofi (sumbangan sembako per bulan dan menghadiri hajatan warga), namun JCM yang diwakili oleh divisi Marketing Communication/Event and Promotion menyadari pentingnya meningkatkan kualitas pendekatan, yaitu melalui community volunteering. Dengan demikian, investasi yang dibangun saat ini tentunya untuk keperluan jangka panjang ke depannya. Pihak pelaksana program mengerti pentingnya berinvestasi secara sosial, dengan menetapkan salah satu tujuan program yaitu mendapatkan dukungan sosial. Investasi sosial yang dilakukan dengan warga akan kembali ketika JCM akan butuh dukungan dari masyarakat sekitar dalam satu situasi krisis ke depannya.

3. Kewajiban Etis - bisnis harus mempunyai tanggung jawab sosial karena tindakan yang bertanggungjawab merupakan hal yang benar untuk dilakukan

Peneliti menilai pihak JCM sudah cukup menyadari kewajiban sosial ini. Dalam teorinya, terdapat tiga tanggung jawab perusahaan (corporate responsibiities) yaitu tanggung jawab ekonomi, tanggung jawab hukum, dan tanggung jawab sosial. Pihak JCM melalui program CSR-nya sudah menunjukkan kesadaran tanggung jawab tersebut, tidak hanya mementingkan keuntungan finansial saja.

4. Citra Publik - bisnis dapat menciptakan citra yang baik dengan mengejar tujuan sosial

Tujuan perusahaan menjalin kegiatan komunikasi dengan masyarakat salah satunya adalah membangun citra yang baik. Terutama dalam kegiatan kehumasan, pembangunan citra perusahaan di mata masyarakat dianggap sangat penting demi keberadaan perusahaan di tengah masyarakat lokal maupun luas. Program sosial JCM selalu di bawah koordinasi dan urusan divisi Marketing Communication/Event and Promotion, yang mana di dalamnya terdapat fungsi PR atau humas. Insting seorang PRO pasti tidak lepas dari tujuan sosial yang dapat meningkatkan citra dan reputasi perusahaan, tidak terkecuali PRO JCM.

5. Lingkungan yang lebih baik - keterlibatan bisnis dapat membantu pemecahan masalah sosial yang sulit

Bagian dari melakukan investasi sosial adalah pengantisipasian krisis. Seperti yang telah disebutkan, program CSR JCM ditujukan untuk meningkatkan hubungan baik yang 
Diterbitkan oleh Program Studi IImu Komunikasi

Universitas Ahmad Dahlan Yogyakarta

sudah ada dengan warga dan mendapatkan dukungan sosial. Hal tersebut berarti tujuan ini bersifat jangka panjang. Dengan adanya tindakan sosial yang bertujuan jangka panjang, secara tidak langsung tindakan ini bertujuan pula untuk mengantisipasi krisis ke depannya dengan pihak warga.

6. Penguasaan Sumber Daya - bisnis mempunyai sumber daya untuk mendukung proyek publik dan proyek amal yang membutuhkan bantuan

Dalam bahasan konteks penelitian ini, program 'masak besar' sangat kental dengan keterlibatan langsung anggota-anggota baik dari pihak masyarakat maupun perusahaan. Sifat dari program sendiri adalah kolaboratif sehingga kerja sama dari banyak pihak terkait sangat terasa.

7. Mengutamakan Pencegahan daripada Perbaikan - bisnis seharusnya mengatasi masalah sosial sebelum mereka menjadi lebih serius dan makin mahal untuk diperbaiki

Ini lah yang menjadi inti dari pelaksanaan program CSR melalui pendekatan investasi sosial. Seperti yang banyak disebutkan sebelumnya, CSR dengan basis investasi sosial ditujukan untuk mengantisipasi terjadinya krisis. Kesadaran ini sudah dimiliki oleh pihak JCM. Konflik yang sempat terjadi di awal pembangunan gedung perusahaan di tengahtengah lingkungan warga menjadikan pihak perusahaan sadar untuk perlu mengatasi konflik yang sempat muncul. Dan untuk meredam dan mengantisipasi konflik ke depannya, pihak JCM melakukan pendekatan sosial melalui program CSR-nya.

\section{KESIMPULAN}

Pelaksanaan CSR di mana masyarakat sekitar perusahaan menjadi target sasaran utama program menjadi ideal ketika tujuannya untuk mengantisipasi krisis. Program CSR yang hanya berbentuk filantrofi hanya meninggalkan efek sosial yang sementara -selama sumbangan atau donasi masih berjalan, namun ketika program sudah berhenti, masyarakat dapat menjadi resah terhadap sikap perusahaan. Berdasarkan hasil penelitian ini Jogja City Mall sebagai organisasi bisnis berbasis layanan konsumen berupa pusat perbelanjaan sudah memiliki kesadaran terhadap pentingnya menggunakan CSR sebagai tindakan antisipatif terhadap krisis. Selain program-program yang selama ini rutin dilakukan seperti program filantrofi berupa sumbangan sembako dan menghadiri hajatan warga, pihak JCM menyadari pentingnya meningkatkan kualitas program sosial (CSR) melalui pendekatan yang berbeda, yaitu dalam hal ini community volunteering. Program sosial yang menggunakan pendekatan community volunteering mengedepankan keterlibatan langsung anggota-anggota terkait secara fisik. Dalam hal ini, Jogja City Mall menggunakan pendekatan sosial melalui community volunteering dari pihak karyawan internal manajemen JCM, 25 rekan media, 35 chef dari hotel-hotel di Yogyakarta dan Magelang (melalui Indonesian Chef Association), dan tidak lupa dari anggota warga sekitar perusahaan.

Peneliti menilai pelaksanaan CSR dengan tema 'masak besar' yang dilakukan oleh JCM cukup efektif dan efisien. Efektif, warga masyarakat yang hadir melebihi yang diperkirakan dan warga masyarakat turun secara sukarela membantu ikut memasak bersama pihak chef. Kesukarelaan dari warga tersebut secara langsung menjadi bukti keberhasilan program. Pendekatan semacam ini memiliki efek tersendiri, yaitu timbul perasaan dari pihak warga bahwa perusahaan (JCM) tidak melepas diri secara bisnis tapi membuka diri 
untuk menerima warga untuk masuk ke dalam lingkungan perusahaan melalui undangan khusus.

Investasi sosial yang dilakukan oleh JCM terhadap warga sekitar perusahaan terlihat jelas dalam proses perencanaan program. Tujuan yang ditetapkan dari pelaksanaan program 'masak besar' JCM mengandung dua poin yaitu (a) untuk meningkatkan hubungan baik dengan warga, dan (b) untuk mendapatkan dukungan sosial dari warga. Poin kedua dalam tujuan program tersebut membuktikan bahwa pihak JCM sedang menanam investasi (sosial) dengan warganya karena suatu saat ketika pihak perusahaan membutuhkan dukungan dari warga perusahaan akan mudah mendapatkannya. Tindakan seperti itu mengarah ke investasi sosial demi antisipasi krisis yang mungkin akan terjadi ke depannya.

\section{Daftar Pustaka}

Budiani, N. (2007). Efektivitas Program Penanggulangan Pengangguran Karang Taruna "Eka Taruna Bhakti" Desa Sumerta Kelod Kecamatan Denpasar Timur Kota Denpasar. Jurnal Ekonomi dan Sosial INPUT , 2 (No.1).

Drucker, P. (2008). Management Revised Edition. California: HarperCollins.

Handoko. (2001). Efektivitas Organisasi. Jakarta: Erlangga.

KPMG International. (2014). Sustainable Insight: Unlocking The Value of Social Investment. Belanda: KPMG.

Poerwandari, K. (2001). Pendekatan Kualitatif Untuk Penelitian Perilaku Manusia. Universitas Indonesia, Fakultas Psikologi. Jakarta: Lembaga Pengembangan Sarana Pengukuran dan Pendidikan Psikologi (LPSP3).

Robbins, S., \& Coutler, M. (2010). Manajemen. Jakarta: Erlangga.

Supriyono. (2000). Sistem Pengendalian Manajemen. Jakarta: Erlangga.

Suryabrata, S. (1992). Metode Penelitian. Yogyakarta: University Gadjah Mada Press. 